\title{
Identifikasi Protozoa Usus Oportunistik dan Faktor Risikonya Pada Anak Panti Asuhan Kota Pekanbaru
}

\author{
Esy Maryanti $^{{ }^{*}}$, M. Reyhan Ahza Hamidy ${ }^{2}$, Lilly Haslinda ${ }^{1}$
}

\begin{abstract}
Opportunistic intestinal protozoa are protozoa that can infect humans at a time when the body's defense system is declining (immunocompromising). Opportunistic protozoan infections are infections by intestinal protozoa that were not previously considered important, but now can cause disease in humans. Opportunistic intestinal protozoan infections besides being found in immunocompromised patients are also reported to infect children. Some of the intestinal protozoan species that have been identified to cause infection are Cryptosporidium sp, Isospora belii, Cyclospora sp, and Blastocystis hominis. This study was an analytical study with a cross sectional design conducted in June 2018 until January 2019. In this study, modified Ziehl-Neelsen staining was used and the results were $25.6 \%$ of orphanages infected with opportunistic intestinal protozoa, which consisted of Cryptosporidium sp. as much as $14.1 \%$, Blastocystis hominis as much as $4.6 \%$, infection with a mixture of Cryptosporidium sp and Blastocystis hominis as much as $4.6 \%$, Isospora belii as much as $2.3 \%$, and no infection by Cyclospora cayetanensis. There was no association between opportunistic intestinal protozoan infections with poor handwashing habits, bowel habits, food hygiene, drinking water treatment, and bad animal raising habits.
\end{abstract}

Key word: opportunistic intestinal protozoan, risk factor, orphanage children

Infeksi protozoa usus merupakan masalah kesehatan di dunia khususnya negara berkembang dan akhir-akhir ini perhatian terhadap infeksi protozoa usus semakin meningkat khususnya infeksi protozoa usus oportunistik. Infeksi protozoa usus oportunistik merupakan infeksi oleh protozoa usus yang dulu tidak dianggap penting namun sekarang dapat menimbulkan penyakit pada manusia. ${ }^{1}$

Penelitian di Jakarta tahun 2008 terdapat 34,6\% kasus kriptosporidiosis pada anak dengan atau tanpa diare. ${ }^{2}$ Beberapa spesies protozoa intestinal yang telah diidentifikasi dapat menyebabkan infeksi diantaranya Cryptosporidium sp, Isospora belli, Cyclospora sp, dan Blastocystis hominis. ${ }^{3}$

Protozoa usus oportunistik sering kali terjadi beriringan dengan penyakit-penyakit yang

\footnotetext{
* Penulis untuk korespondensi : Email : esy.maryanti@ gmail.com

1 KJFD Parasitologi Fakultas Kedokteran Universitas Riau, Pekanbaru, Riau

2 Program Studi Kedokteran Fakultas Kedokteran Universitas Riau, Pekanbaru, Riau
}

menurunkan kekebalan tubuh seperti Human Immunodeficiency Virus (HIV), tuberkulosis dan penyakit dengan gangguan sistem imun lainnya. Penghancuran sistem imun oleh penyakit HIV yang progresif menyebabkan penurunan jumlah dari sel darah putih terutama CD $4(<200$ hingga $<50)$ dan dapat memberikan dampak mudahnya terjadi infeksi yang disebabkan oleh berbagai jenis mikroorganisme oportunistik salah satunya protozoa usus oportunistik. $^{4}$

Infeksi protozoa usus oportunistik tersebut selain ditemukan pada pasien immunocompromise juga dilaporkan dapat menginfeksi anak. Pada kasus kriptosporidiosis yaitu infeksi oleh Cryptosporidium $s p$, dilaporkan lebih sering menginfeksi anak-anak khususnya balita (bawah lima tahun) dan diperkirakan berhubungan erat dengan status imun anak. ${ }^{5}$ Manifestasi klinis dari infeksi tersebut tergantung kepada status imun penderita, mulai dari asimptomatis sampai dengan gejala berat seperti diare kronis yang tidak sembuh dan berakibat fatal. Infeksi ini sering ditemukan pada individu immunocompromise. ${ }^{1}$ 
Perilaku higiene dan sanitasi serta akses terhadap air besih dapat berpengaruh terhadap infeksi parasit oportunistik. Pada penelitian meta-analisis, hal ini menunjukkan penurunan 33\% terjadinya infeksi dengan parilaku higienis dan akses terhadap air bersih. Penularan penyakit infeksi protozoa usus ini sangat mudah terutama pada daerah-daerah dengan sanitasi dan higienis yang masih buruk. Gejala yang berulang dan mudahnya penularan infeksi parasit ini akan menyebabkan angka kesakitan yang tinggi yang sangat berpengaruh kepada kualitas hidup manusia. ${ }^{3}$

Beberapa tempat dengan kondisi higiene lingkungan yang kurang baik dapat dijumpai di pasar, tempat pembuangan akhir (TPA) dan panti asuhan. Panti asuhan adalah lembaga kesejahteraan sosial yang mempunyai peran untuk memberikan layanan kesejahteraan sosial pada anak-anak yang terlantar. Kehidupan anak-anak yang tinggal di panti asuhan pada umumnya tinggal dalam hunian yang padat dan lembab. Kebiasaan pola hidup anak-anak panti asuhan yang sering bertukar pakaian, handuk, sarung bahkan sampai bertukar bantal, guling maupun kasur tidur. Oleh karena itu, pada anak-anak masalah ini lebih banyak dialami, karena individu tersebut belum mampu secara mandiri melakukan kebersihan diri dan kebersihan lingkungan. Kondisi anak yang kurang memperhatikan perilaku kesehatan membuat mereka lebih rentan untuk tertular penyakit. ${ }^{6}$ Berdasarkan hal tersebut yaitu masih tingginya angka kejadian protozoa usus oportunistik pada anak juga beberapa faktor salah satunya keadaan anak serta kondisi panti asuhan yang kurang terutama dalam hal higiene personal dan lingkungan, peneliti tertarik untuk melakukan penelitian apakah terdeteksi protozoa usus oportunistik pada tinja anak panti asuhan Kota Pekanbaru.

\section{METODE}

Penelitian ini bersifat analitik dengan disain cross sectional. Pada penelitian ini akan diidentifikasi protozoa usus oportunistik pada feses anak-anak di panti asuhan Kota Pekanbaru serta melihat faktor risiko yang dapat menyebabkan terjadinya infeksi oleh protozoa usus oportunistik. Panti asuhan yang dijadikan sebagai tempat penelitian adalah enam panti asuhan yang ada di Kota Pekanbaru. Pemeriksaan sampel dilakukan di Laboratorium Parasitologi FK UNRI yang dilakukan pada bulan Juni 2018 sampai bulan Januari 2019. Jumlah sampel yang memenuhi kriteria inklusi dan eksklusi berjumlah 43 orang.

Pengambilan sampel dilakukan setelah memberikan penjelasan kepada pemimpin panti asuhan dan anak-anak panti tentang prosedur penelitian. Setelah penjelasan, pemimpin panti asuhan dan anak-anak diberi informed consent dan kuesioner yang harus diisi serta diberikan pot tinja yang memiliki nomor yang sama dengan kertas kuesioner. Kuesioner diisi dengan memberikan pertanyaan kepada pemimpin panti asuhan dan anak anak melalui wawancara terpimpin. Sampel tinja yang diambil adalah tinja segar yang ditampung secara langsung oleh responden dan diserahkan ke peneliti dalam waktu kurang dari 24 jam.

Tinja yang didapatkan dibawa ke Laboratorium Parasitologi Fakultas Kedokteran Universitas Riau untuk dicampurkan dengan formalin 10\% dengan perbandingan 1:3. Selanjutnya dilakukan pewarnaan sediaan langsung dengan teknik Modifikasi Tahan Asam (MTA) dan dilihat di bawah mikroskop dengan pembesaran $100 x .^{3}$

\section{HASIL}

\section{Karakteristik reponden penelitian}

Responden penelitian adalah anak panti asuhan yang ada di enam panti asuhan di Kota Pekanbaru. Jumlah seluruh sampel sebanyak 43 orang. Karakteristik responden dapat dilihat pada Tabel 1 sebagai berikut. 
Tabel 1. Karakteristik responden berdasarkan jenis kelamin, umur dan tingkat pendidikan

\begin{tabular}{|c|c|c|}
\hline \multirow{2}{*}{ Variabel } & \multicolumn{2}{|c|}{ Jumlah } \\
\hline & $\mathbf{N}$ & $\%$ \\
\hline \multicolumn{3}{|l|}{ Jenis Kelamin } \\
\hline - Laki-laki & 27 & 62,8 \\
\hline - Perempuan & 16 & 37,2 \\
\hline \multicolumn{3}{|l|}{ Umur } \\
\hline - $\quad 0-1$ Tahun & 0 & 0 \\
\hline - $>1-3$ Tahun & 0 & 0 \\
\hline - $>3-5$ Tahun & 0 & 0 \\
\hline - $\quad>5-12$ Tahun & 36 & 83,7 \\
\hline - $\quad>12-15$ Tahun & 4 & 9,3 \\
\hline - $\quad>15-18$ Tahun & 3 & 7 \\
\hline \multicolumn{3}{|l|}{ Tingkat Pendidikan } \\
\hline - $\mathrm{TK}$ & 1 & 2,3 \\
\hline - $\mathrm{SD}$ & 36 & 83,7 \\
\hline - $\mathrm{SMP}$ & 3 & 7 \\
\hline - $\mathrm{SMA}$ & 3 & 7 \\
\hline
\end{tabular}

Berdasarkan Tabel 1, didapatkan frekuensi jenis kelamin anak-anak panti asuhan terbanyak adalah laki-laki sebanyak 27 (62,8\%) dan rentang umur terbanyak adalah 5-12 tahun sebanyak 36 $(83,7 \%)$ serta tingkat pendidikan terbanyak adalah SD sebanyak $36(83,7 \%)$.

\section{Angka kejadian protozoa usus oportunistik}

Hasil pemeriksaan sampel tinja yang dilakukan di Laboratorium Parasitologi Fakultas Kedokteran Universitas Riau terhadap jumlah kejadian protozoa usus oportunistik pada anak-anak panti asuhan di Kota Pekanbaru dapat dilihat pada Tabel 2.

Tabel 2. Angka kejadian protozoa usus oportunistik

\begin{tabular}{ccc}
\hline Protozoa Usus Oportunistik & N & \% \\
\hline Positif & 11 & 25,6 \\
Negatif & 32 & 74,4 \\
\hline Jumlah & 43 & 100 \\
\hline
\end{tabular}

Berdasarkan Tabel 2 didapatkan angka kejadian positif protozoa usus oportunistik sebanyak $11(25,6 \%)$ anak dan yang negatif sebanyak 32 (74,4\%) anak.
Distribusi kejadian protozoa usus oportunistik berdasarkan jenis kelamin, umur, dan tingkat pendidikan dari 11 sampel anak yang positif terinfeksi protozoa usus oportunistik dapat dilihat pada Tabel 3. 
Tabel 3. Distribusi kejadian protozoa usus oportunistik berdasarkan jenis kelamin, umur, dan tingkat pendidikan $(\mathrm{n}=11)$

\begin{tabular}{|c|c|c|}
\hline \multirow{2}{*}{$\begin{array}{l}\text { Jenis kelamin, umur dan tingkat } \\
\text { pendidikan }\end{array}$} & \multicolumn{2}{|c|}{$\begin{array}{c}\text { Positif protozoa usus } \\
\text { Oportunistik }\end{array}$} \\
\hline & $\mathbf{N}$ & $\%$ \\
\hline \multicolumn{3}{|l|}{ Jenis Kelamin } \\
\hline - Laki-laki & 8 & 72,7 \\
\hline - $\quad$ Perempuan & 3 & 27,3 \\
\hline \multicolumn{3}{|l|}{ Umur } \\
\hline - 5-12 Tahun & 9 & 81,9 \\
\hline - $\quad>12-15$ Tahun & 2 & 18,1 \\
\hline - $\quad>15-18$ Tahun & 0 & 0 \\
\hline \multicolumn{3}{|l|}{ Tingkat Pendidikan } \\
\hline - $\mathrm{TK}$ & 0 & 0 \\
\hline - $\mathrm{SD}$ & 10 & 90,9 \\
\hline - $\quad \mathrm{SMP}$ & 1 & 9,1 \\
\hline - $\mathrm{SMA}$ & 0 & 0 \\
\hline
\end{tabular}

Berdasarkan Tabel 3 didapatkan kejadian protozoa usus oportunistik terbanyak pada laki-laki sebanyak 8 (72,7\%) dengan rentang umur 5-12 tahun sebanyak $9(81,9 \%)$ serta pada tingkat pendidikan SD sebanyak $10(90,9 \%)$.
Angka kejadian protozoa usus oportunistik berdasarkan spesies protozoa yang menginfeksi dapat dilihat pada Tabel 4.

Tabel 4. Hasil pemeriksaan identifikasi protozoa usus oportunistik berdasarkan spesies

\begin{tabular}{ccc}
\hline Hasil pemeriksaan positif & N & \% \\
\hline Cryptosporidium $s p$ & 6 & 14,1 \\
Blastocystis hominis & 2 & 4,6 \\
Cryptosporidium sp + B. hominis & 2 & 4,6 \\
Isospora belii & 1 & 2,3 \\
Cyclospora cayetanensis & 0 & 0 \\
\hline
\end{tabular}

Berdasarkan Tabel 4 didapatkan angka kejadian protozoa usus oportunistik terbanyak yakni Cryptosporidium sp sebanyak $6(14,1 \%)$ anak dan tidak ditemukannya infeksi oleh Cyclospora cayetanensis.

\section{Faktor risiko kejadian protozoa usus oportunistik}

Distribusi faktor risiko kejadian protozoa usus oportunistik dapat dilihat pada Tabel 5. 
Tabel 5. Distribusi frekuensi faktor risiko kejadian protozoa usus oportunistik

\begin{tabular}{|c|c|c|}
\hline \multirow{2}{*}{ Faktor risiko } & \multicolumn{2}{|c|}{ Anak Panti Asuhan } \\
\hline & $\mathbf{N}$ & $\%$ \\
\hline \multicolumn{3}{|l|}{ Kebiasaan mencuci tangan } \\
\hline - Baik & 15 & 34,9 \\
\hline - Buruk & 28 & 65,1 \\
\hline \multicolumn{3}{|l|}{ Kebiasaan buang air besar } \\
\hline - Baik & 41 & 95,3 \\
\hline - Buruk & 2 & 4,7 \\
\hline \multicolumn{3}{|l|}{ Kebersihan makanan } \\
\hline - Baik & 39 & 90,7 \\
\hline - Buruk & 4 & 9,3 \\
\hline \multicolumn{3}{|l|}{ Pengolahan air minum } \\
\hline - Baik & 26 & 60,5 \\
\hline - $\quad$ Buruk & 17 & 39,5 \\
\hline \multicolumn{3}{|c|}{ Kebiasaan memelihara hewan } \\
\hline - Ada & 43 & 100 \\
\hline - $\quad$ Tidak ada & 0 & 0 \\
\hline
\end{tabular}

Berdasarkan data dari Tabel 5, pada anak-anak di panti asuhan diketahui bahwa masih tingginya kebiasaan mencuci tangan tidak menggunakan sabun dan adanya kebiasaan memelihara hewan sedangkan faktor risiko yang tergolong baik yaitu kebiasaan buang air besar, kebersihan makanan dan pengolahan air minum.
Hubungan kejadian protozoa usus oportunistik dengan faktor risiko

Hubungan kejadian protozoa usus oportunistik dengan faktor risiko dapat dilihat pada Tabel 6.

Tabel 6. Hubungan kejadian protozoa usus oportunistik dengan faktor risiko anak panti asuhan (n=43)

\begin{tabular}{|c|c|c|c|c|c|}
\hline \multirow{3}{*}{ Faktor risiko } & \multicolumn{4}{|c|}{ Kejadian protozoa usus oportunistik } & \multirow{3}{*}{$\mathbf{p}$} \\
\hline & \multicolumn{2}{|c|}{ Positif } & \multicolumn{2}{|c|}{ Negatif } & \\
\hline & $\mathbf{N}$ & $\%$ & $\mathbf{N}$ & $\%$ & \\
\hline \multicolumn{6}{|l|}{ Kebiasaan mencuci tangan } \\
\hline - $\quad$ Baik & 4 & 9,3 & 11 & 25,6 & \multirow{2}{*}{1,000} \\
\hline - Buruk & 7 & 16,3 & 21 & 48,8 & \\
\hline \multicolumn{6}{|l|}{ Kebiasaan Buang Air Besar } \\
\hline - Baik & 11 & 25,6 & 30 & 69,7 & \multirow{2}{*}{1,000} \\
\hline - Buruk & 0 & 0 & 2 & 4,7 & \\
\hline \multicolumn{6}{|l|}{ Kebersihan makanan } \\
\hline - Baik & 10 & 23,3 & 29 & 67,4 & \multirow{2}{*}{1,000} \\
\hline - Buruk & 1 & 2,3 & 3 & 7 & \\
\hline \multicolumn{6}{|l|}{ Pengolahan air minum } \\
\hline - Baik & 7 & 16,3 & 19 & 44,2 & \multirow{2}{*}{1,000} \\
\hline - Buruk & 4 & 9,3 & 13 & 30,2 & \\
\hline \multicolumn{6}{|c|}{ Kebiasaan memelihara hewan } \\
\hline - Ada & 11 & 25,6 & 32 & 74,4 & - \\
\hline - $\quad$ Tidak Ada & 0 & 0 & 0 & 0 & \\
\hline
\end{tabular}


Berdasarkan tabel 6. setelah dilakukan uji statistik dengan uji Fisher's Exact didapatkan hasil bahwa tidak terdapat hubungan yang bermakna antara kebiasaan mencuci tangan, kebiasaan buang air besar, kebersihan makanan, pengolahan air minum dan kebiasaan memelihara hewan terhadap kejadian protozoa usus oportunistik.

\section{PEMBAHASAN}

Berdasarkan penelitian yang telah dilakukan didapatkan karakteristik responden berdasarkan jenis kelamin lebih banyak anak laki-laki sebanyak 27 (62,8\%) dibandingkan anak perempuan sebanyak 16 $(37,2 \%)$ dan untuk rentang umur terbanyak pada rentang umur 5-12 tahun serta tingkat pendidikan terbanyak yaitu sekolah dasar (SD).

Penelitian ini sejalan dengan penelitian yang dilakukan pada anak-anak yang berobat ke puskesmas rawat inap di Pekanbaru tahun 2012 dengan hasil didapatkan jumlah anak laki-laki lebih banyak daripada anak perempuan yaitu 53 orang (55,21\%). ${ }^{7}$ Hal ini juga didukung oleh penelitian Saputra tahun 2017 yang menunjukkan hasil dengan karakteristik umur anak terbanyak yaitu 96 anak (96\%) dengan rentang umur 9-11 tahun. ${ }^{8}$

Hasil penelitian yang dilakukan pada enam panti asuhan di Kota Pekanbaru, didapatkan anak panti asuhan yang terinfeksi protozoa usus oportunistik sebanyak 11 (25,6\%) anak. Penelitian ini sesuai dengan penelitian tahun 2012 yang hasil penelitiannya menunjukkan bahwa 17 (22,3\%) anak positif terinfeksi protozoa usus oportunistik. Hal ini didukung kepustakaan bahwa pada anak kekebalan alami tubuhnya belum terbentuk sempurna sehingga mudah terinfeksi oleh berbagai macam mikroorganisme salah satunya protozoa usus oportunistik. Tingkat pengetahuan dan perilaku anak dalam menjaga kebersihan dan sanitasi diri serta lingkungannya juga masih rendah dan kurang sehingga membuat mudahnya mikroorganisme masuk ke dalam tubuh anak. ${ }^{6}$

Penelitian yang telah dilakukan didapatkan anak panti asuhan yang berjenis kelamin laki-laki sebanyak 27 anak, yang terinfeksi sebanyak 8 (72,7\%) anak. Infeksi protozoa usus oportunistik lebih banyak terjadi pada laki-laki kemungkinan disebabkan karena anak laki-laki lebih aktif bermain diluar panti asuhan dan kurang peduli terhadap kebersihan dirinya dan sanitasi lingkungannya. Penelitian ini sejalan dengan penelitian pada tahun 2012 di Pekanbaru, didapatkan hasil dari seluruh anak yang menjadi responden terdapat 17 anak yang positif terinfeksi protozoa usus oportunistik dan yang terbanyak adalah anak berjenis kelamin laki-laki sebanyak $9(11,8 \%)$ anak dan perempuan sebanyak $8(10,5 \%)$ anak. Berdasarkan penelitian tersebut menunjukkan laki-laki lebih banyak terinfeksi daripada perempuan, tetapi risiko untuk terjadi infeksi tersebut bisa terjadi pada semua orang tergantung perilaku higienenya. ${ }^{6}$

Hasil penelitian yang peneliti dapatkan umur terbanyak yaitu 5-12 tahun dengan infeksi sebanyak 9 (81,9\%) anak. Hal ini kemungkinan disebabkan karena pada saat observasi dan hasil data dari pihak panti asuhan bahwa anak panti asuhan terbanyak pada rentang umur 5-12 tahun dan juga karena infeksi protozoa usus oportunistik lebih rentan menginfeksi individu yang kurang menjaga higienitas dirinya. Penelitian ini sesuai dengan penelitian yang dilakukan oleh Al-Shamiri di Taiz tahun 2007 didapatkan infeksi protozoa usus oportunistik pada anak dengan rentag umur 1-12 tahun sebesar 3,1\%. ${ }^{9}$ Hal itu kemungkinan disebabkan infeksi lebih rentan pada umur yang masih kecil karena belum bisa memilah kebiasaan yang baik untuk higienitasnya.

Tingkat pendidikan yang didapatkan peneliti dari penelitian ini terbanyak pada jenjang pendidikan Sekolah Dasar (SD) sebanyak 10 (90,9\%) anak. Jenjang pendidikan SD merupakan tempat dimana anak masih dalam tahap awal proses belajar, sehingga belum memiliki pengetahuan tentang pentingnya menjaga kebersihan dan sanitasi untuk mencegah dampak buruk terhadap kesehatannya, sedangkan pada jenjang pendidikan SMP dan SMA tahun sudah merupakan tahap lanjut dari proses belajar anak, sehingga memiliki pengetahuan tentang pentingnya menjaga kesehatan dengan menjaga kebersihan diri dan lingkungan. ${ }^{10} \mathrm{Hal}$ ini sejalan dengan penelitian yang dilakukan Saputra tahun 2017 didapatkan hasil bahwa anak yang positif terinfeksi berada pada jenjang SD sebanyak 6 (6\%) anak. ${ }^{11}$

Berdasarkan hasil penelitian infeksi protozoa usus oportunistik pada anak di enam panti asuhan di Kota Pekanbaru dengan menggunakan metode pewarnaan MTA menunjukkan hasil infeksi yang 
didapat 25,6\% dengan infeksi tertinggi ditemukan Cryptosporidium sp sebanyak $14,1 \%$, diikuti infeksi oleh Blastocystis hominis sebanyak 4,6\%, infeksi campuran Cryptosporidium sp dan Blastocystis hominis sebanyak 4,6\%, infeksi oleh Isospora belii sebanyak 2,3\%, dan tidak ditemukannya infeksi oleh Cyclospora cayetanensis pada seluruh sampel. Kriptosporidiosis rentan terjadi pada anak usia 1-5 tahun, wanita hamil dan individu immunokompromis. ${ }^{12}$ Penularan kriptosporidosis sangat mudah terutama pada daerah dengan sanitasi dan higiene buruk serta kebiasaan kontak dengan hewan. ${ }^{1}$

Berdasarkan penelitian yang dilakukan oleh Kurniawan tahun 2007 melaporkan sebanyak 34\% tinja anak batita (bawah tiga tahun) di Jakarta positif dengan Cryptosporidium sp. ${ }^{4} \mathrm{Hal}$ ini menunjukkan masih tingginya angka kejadian infeksi oleh Cryptosporidium sp yang dihubungkan dengan kebersihan dan sanitasi yang kurang baik dari masyarakat.

Infeksi oleh Isospora belii pada penelitian ini didapatkan satu orang anak panti asuhan yang terinfeksi. Hal ini bisa terjadi karena kondisi panti asuhan yang kurang terawat sehingga ookista dari I. belii dapat hidup pada kondisi lingkungan yang kotor dan lembab serta dari makanan, air atau permukaan lingkungan lainnya seperti tanah yang terkontaminasi oleh tinja yang mengandung ookista I. belii. Penelitian ini sejalan dengan penelitian yang dilakukan Wulandari tahun 2016 dimana dari hasil penelitiannya didapatkan adanya infeksi oleh I. belii sebanyak 1 (3\%) orang pada pekerja sampah. Hal ini disebabkan karena pada penelitian ini responden juga sering berada pada lingkungan yang kurang terawat dan kurang bersih, sehingga adanya kontaminasi makanan, air, dan tanah sekitar petugas bekerja oleh I. belii. $^{13}$

Berdasarkan penelitian yang dilakukan peneliti, ditemukan infeksi oleh Blastocystis hominis pada empat orang anak. Penelitian ini sejalan dengan penelitian oleh Wulandari tahun 2016, dimana dari 4 sampel anak yang positif didapatkan hasil sampel yang positif ookista dari Blastocystis hominis sebanyak 1 (3\%). Hal ini kemungkinan dapat terjadi karena individu dengan praktik higienis yang kurang, dan kontak dengan hewan atau mengonsumsi makanan atau air yang terkontaminasi kista $B$. hominis dapat meningkatkan risiko terinfeksi. ${ }^{14}$

Berdasarkan penelitian ini tidak ditemukan adanya infeksi oleh Cyclospora cayetanensis, hal ini kemungkinan dikarenakan teknik MTA kurang sensitif dalam pemeriksaan protozoa atau responden memang tidak terinfeksi oleh Cyclospora cayetanensis. Literatur lain menyebutkan bahwa infeksi oleh Cyclospora cayetanensis sering dikaitkan dengan wisatawan yang kembali dari kunjungan ke luar negeri. ${ }^{12}$

Berdasarkan hasil analisis menggunakan program komputerisasi menggunakan uji statistik Chi-square dengan menghubungkan kejadian infeksi protozoa usus oportunistik pada anak panti asuhan dengan faktor risiko, didapatkan seluruh faktor risiko yang diteliti mempunyai nilai Expected Count (E) < 5 sehingga tidak memenuhi syarat untuk dilakukan uji Chi Square terhadap faktor risiko tersebut. Oleh karena itu, dilakukan pengujian menggunakan uji alternatif dengan uji Fisher's Exact dan didapatkan hasil bahwa tidak terdapat hubungan yang bermakna antara kebiasaan mencuci tangan, kebiasaan buang air besar, kebersihan makanan, pengolahan air minum dan kebiasaan memelihara hewan terhadap kejadian protozoa usus oportunistik. Hal ini kemungkinan karena terdapat faktor risiko lain untuk terjadinya infeksi protozoa usus oportunistik yang berada di luar panti asuhan. Berdasarkan penelitian yang dilakukan Khalakdina tahun 2003 di San Fransisco terdapat faktor lain yang dapat mempengaruhi terjadinya infeksi protozoa usus oportunistik, seperti sosio ekonomi yang rendah, sistem imun tubuh yang rendah, dan orang yang berpergian ke luar, yang dimana akan memudahkan terjadinya infeksi dan meningkatkan angka kejadian infeksi protozoa usus oportunistik. ${ }^{15}$

\section{SIMPULAN}

Karakteristik anak-anak panti asuhan berdasarkan jenis kelamin yang terbanyak adalah laki-laki dengan rentang umur 5-12 tahun serta tingkat pendidikan pada tingkat Sekolah Dasar (SD). Angka kejadian protozoa usus oportunistik sebanyak 25,6\% dengan spesies protozoa yang menginfeksi yaitu infeksi oleh Cryptosporidium sp sebanyak $14,1 \%$ diikuti infeksi oleh Blastocystis hominis sebanyak 4,6\%, infeksi campuran Cryptospotridium 
sp dan Blastocystis hominis sebanyak 4,6\%, infeksi oleh Isospora belii sebanyak 2,3\%, dan tidak didapatkannya infeksi oleh Cyclospora cayetanensis. Tidak terdapat hubungan yang bermakna antara faktor risiko kebiasaan mencuci tangan, kebiasaan buang air besar, kebersihan makanan, pengolahan air minum, dan kebiasaan memelihara hewan terhadap kejadian protozoa usus oportunistik.

\section{DAFTAR PUSTAKA}

1. Susanto L, Gandahusada S, Coccidia. Dalam parasitologi kedokteran. Ed.4. Jakarta: Balai Penerbit FKUI; 2008: 158-79

2. Kurniawan A, Dwintasari SW, Soetomenggola HA, Wanani SI. Detection of Cryptosporidium $s p$ infections by PCR and modified acid fast staining from potassium dichromate preserved stool. Medical Journal of Indonesia. 2009;18(3)

3. Arya IF, Pratiwi A. Identifikasi parasit intestinal penyebab infeksi oportunistik dengan studi pengetahuan, sikap, dan perilaku mengenai higiene pada penderita HIV/AIDS. JSK. 2015;1(1).

4. Bourgeois A, Sarfati C, Menotti J. Prevalence of intestinal parasites including Microsporidia in Human Immunodeficiency Virus infected adults in Cameroon: A Cross Sectional Study. Jan 2007:162-4. Available from: http:// www.ajmth.org/content/journals/10.4269/ ajmth.2006.74.162

5. Hunter PR, Nichols G. Epidemiology and clinical features of Cryptosporidium infection in immunocompromised patients. Clin Microbiol Rev. 2002; 15(1):145-54

6. Triani E, Hidajat D, Setyorini RH, Cenderadewi M. Hubungan kebersihan pribadi dan sanitasi lingkungan dengan kejadian skabies pada anakanak di Panti Asuhan Al Hidayah Mataram. Jurnal Kedokteran Unram. 2017;6(2):9-11
7. Maryanti E, Lesmana SD, Mandela H. Deteksi protozoa usus oportunistik pada penderita diare anak di puskesmas rawat inap Kota Pekanbaru. JIK. 2015; 9(1): 22-6

8. Saputra I, Sari M, Gunardi W. Prevalensi infeksi protozoa usus pada siswa sekolah dasar negeri paponggo 01 Jakarta Utara tahun 2016. Jurnal Kedokteran Meditek. 2017; 23

9. Al-Shamiri AH, Al-Zubairy AH, Al-Mamari RF. The prevalence of Cryptosporidium sp. in children, Taiz District Yemen. Irania J Parasitol. Februari. 2010; 5 (2): 26-32

10. Rebecca O. Aprilia D. Fia M. Hubungan infeksi parasit usus dengan pengetahuan perilaku hidup bersih sehat pada anak SD Bekasi, 2012. eJKI. 2015; 3(1)

11. Gandahusada S, Illahude HD, Pribadi W. Parasitologi kedokteran. Jakarta: Balai Penerbit FKUI; 2013. p. 103

12. Crowley B, Path C, Maloney C, Keane TC. Cyclspora species a cause of diarrhea among Irish trevellers to Asia. Ir Med J. 1996; 89: 1102

13.Garcia L.S, Bruckner D.A. Diagnostik parasitologi kedokteran. Jakarta: Buku Kedokteran EGC; 1996. P. 41-50

14.Tan KS. New insight on classification, identification, and clinical relevance of Blastocystis sp. Clin Microbiol Rev. 2008; 21(4): 639-665.

15. Khalakdina A, Vugia DJ, Nadle J, Rothrock GA, Jr JMC. Is drinking water a risk factor for endemic cryptosporidiosis? A case control in the immunocompetent general population of the San Fransisco Bay Area. BMC Public Health. 2003; 3(11): 8-10. 